\title{
The potential of coffee stems gasification to provide bioenergy for coffee farms: a case study in the Colombian coffee sector
}

\author{
Samira Garcia-Freites ${ }^{1}$ (D) - Andrew Welfle ${ }^{1} \cdot$ Amanda Lea-Langton $^{1} \cdot$ Paul Gilbert ${ }^{1,2} \cdot$ Patricia Thornley $^{1,3}$
}

Received: 24 April 2019 /Revised: 1 July 2019 / Accepted: 15 July 2019 / Published online: 3 August 2019

(C) The Author(s) 2019

\begin{abstract}
The coffee industry constitutes an important part of the global economy. Developing countries produce over $90 \%$ of world coffee production, generating incomes for around 25 million smallholder farmers. The scale of this industry poses a challenge with the generation of residues along with the coffee cultivation and processing chain. Coffee stems, obtained after pruning of coffee trees, are one of those abundant and untapped resources in the coffee supply chain. Their high lignocellulosic content, the low calorific value ranging between 17.5 and $18 \mathrm{MJ} \mathrm{kg}^{-1}$ and the low ash content make them a suitable solid fuel for thermochemical conversion, such as gasification. This research evaluates the feasibility of using these residues in small-scale downdraft gasifiers coupled to internal combustion engines for power and low-grade heat generation, using process modelling and the Colombian coffee sector as a case study. The producer gas properties $\left(5.6 \mathrm{MJ} \mathrm{Nm}^{-3}\right.$ ) and the gasifier's performance characteristics suggest that this gas could be utilized for power generation. A cogeneration system efficiency of $45.6 \%$ could be attainable when the system's low-grade heat is recovered for external applications, like in the coffee drying stage. An analysis of the energy demand and coffee stems availability within the Colombian coffee sector shows that the biomass production level in medium- to large-scale coffee farms is well matched to their energy demands, offering particularly attractive opportunities to deploy this bioenergy system. This work assesses the feasibility of providing coffee stem-sourced low-carbon energy for global coffee production at relevant operating scales in rural areas.
\end{abstract}

Keywords Gasification · Coffee residues · Process modelling $\cdot$ Power and heat generation · Coffee sector · Energy demand

\author{
Abbreviations \\ CHP Combined heat and power \\ CGE Cold gas efficiency \\ daf Dry ash-free composition \\ d.b. Dry-basis composition \\ ER Equivalence ratio \\ HGE Hot gas efficiency
}

$\overline{\text { Paul Gilbert and Patricia Thornley this work was done while having }}$ affiliation to the University of Manchester.

Samira Garcia-Freites

samira.garciafreites@manchester.ac.uk

1 Tyndall Centre for Climate Change Research, School of Mechanical, Aerospace and Civil Engineering, University of Manchester, Manchester, UK

2 Scottish Borders Council, Council Headquarters, Newton St. Boswells, Melrose, UK

3 Supergen Bioenergy Hub, European Biomass Research Institute (EBRI), Aston University, Birmingham B4 7ET, UK
ICE Internal combustion engine

LI Low income

LMI Low-middle income

LHV Low heating value

MC Moisture content

UMI Upper-middle income

\section{Introduction}

\subsection{International context of coffee production}

Coffee is an important global commodity, with a market that has shown significant resilience in a world with a changing agricultural economy, where coffee production has grown $3.5 \%$ per year since 2008 , faster than $2.5 \%$ overall growth in agriculture [1]. The majority of coffee consumption occurs in industrialized countries, yet over $90 \%$ of world coffee production takes place in low- and middle-income countries $[2,3]$ and around 120 million people depend on coffee farming and 
trading for their livelihood [4]. As developing countries, many of them face energy access problems, with a significant part of their population lacking access to electricity and clean cooking [5, 6]. Table 1 collates data from the top 10 coffee producer countries, indicating also the population without access to electricity and clean cooking.

The coffee industry generates vast amounts of by-products and residues along the cultivation, harvesting and processing chain [7], posing health, environmental and economic issues. Hence, the projected rise of coffee production for the coming years calls for a more sustainable approach in the utilization of the coffee supply chain by-products [2]. The use of these residues could be further improved in more efficient applications , considering their physical and chemical characteristics. They could be upgraded into substrates for bioprocesses $[2,7]$ or used as fuels for energy conversion to feedback into the coffee agro-industry and rural communities [8]. These potential opportunities would add value to the coffee industry by improving the sustainability of the sector in terms of waste management, energy self-generation and additional revenue for the coffee farmers.

Currently, from the range of residues in the coffee processing chain, the coffee husks and coffee pulps have both applications as silage, due to their high concentration of potassium and other mineral nutrients, and for composting and vermicomposting $[2,9]$. For bioenergy generation, coffee husks have been utilized as a solid fuel for heat generation. Coffee pulps, a more abundant resource with higher moisture content, have had more applicability in biogas and bioethanol production [9]. On the other hand, the coffee grounds, obtained from the coffee brewing process, have potential applications in composting, like dietary fibre, and substrate for mushroom cultivation. On the energy side, they are used as a solid fuel in boilers of coffee brewing factories and have a high-energy potential as a feedstock for biogas, bioethanol and biodiesel production [10]. These applications consume only a fraction of the resources available [2]. Another portion is burned in cookstoves, in open fields or disposed on land until decomposition, deriving in health and environmental problems [11], still remaining untapped or inefficiently used $[2,8,10-15]$.

The coffee stems, another residue produced during coffee trees pruning, also represent a significant resource in the coffee supply chain $[12,16]$, yet they have received little research attention, compared with other residues, such as the coffee husks, pulp and grounds. Coffee stems feature more advantageous properties for thermochemical conversion processes, having more lignocellulosic material, lower ash content and higher LHV (see Table 2), compared with other coffee residues (e.g. coffee husks and grounds) [7].

Therefore, this paper explores the resource potential and bioenergy conversion feasibility of coffee stems into energy vectors that could potentially tackle energy access problems in many rural areas of these countries and/or supply low-carbon energy to the coffee agro-industry. It could also reduce the impact of the carbon footprint of the production of this internationally traded commodity. This work expands existing knowledge by assessing the viability of providing bioenergy for global coffee production at relevant operating scales in coffee farms. The work explores case studies in Colombia, the third-largest coffee producer country, and considers the technical viability of implementation and associated impacts.

\subsection{The context of renewable energies in Colombia}

Colombia has large potential for power generation from different renewable sources, hydro (93 GW), wind (25 GW),

Table 1 Top 10 coffee producer countries and their population without energy access $[3,5,6]$

\begin{tabular}{llllll}
\hline Rank & Country $^{\mathrm{a}}$ & $\begin{array}{l}\text { Coffee production } \\
\text { (tons of beans) }\end{array}$ & $\begin{array}{l}\text { Population without } \\
\text { electricity (2016) }\end{array}$ & $\begin{array}{l}\text { Population relying on } \\
\text { biomass for cooking (2015) }\end{array}$ & $\begin{array}{l}\text { Coffee stem biomass } \\
\text { potential (tons) }\end{array}$ \\
\hline 1 & Brazil (UMI) & $2,592,000$ & $<1,000,000$ & $7,700,000$ & $7,069,091$ \\
2 & Vietnam (LMI) & $1,650,000$ & $1,600,000$ & $35,800,000$ & $2,209,091$ \\
3 & Colombia (UMI) & 810,000 & $1,100,000$ & $5,800,000$ & $1,800,000$ \\
4 & Indonesia (LMI) & 660,000 & $23,000,000$ & $67,300,000$ & $1,047,273$ \\
5 & Ethiopia (LI) & 384,000 & $60,700,000$ & $93,100,000$ & 949,091 \\
6 & Honduras (LMI) & 348,000 & $1,900,000$ & $94,000,000$ & 78,091 \\
7 & India (LMI) & 348,000 & $239,200,000$ & $779,700,000$ & 785,455 \\
8 & Uganda (LI) & 288,000 & $32,500,000$ & $37,900,000$ & 638,182 \\
9 & Mexico (UMI) & 234,000 & - & - & 556,364 \\
10 & Guatemala (LMI) & 204,000 & $1,000,000$ & $4,900,000$ & \\
\hline
\end{tabular}

${ }^{\mathrm{a}}$ The countries are classified according to the World Bank Country Income classification as follows: UMI, upper-middle income; $L M I$, lower middle income; and $L I$, low income

${ }^{\mathrm{b}}$ Estimation of coffee stem biomass potential from the conversion factor of dry parchment coffee production per year (1-kg dry parchment coffee yield 2.7-kg coffee stems) 
Table 2 Chemical structureproximate and elemental analyses of coffee stems, taken from Garcia et al. [16]

\begin{tabular}{llllll}
\hline $\begin{array}{l}\text { Proximate analysis } \\
(\% \text { wt. dry basis })\end{array}$ & & $\begin{array}{l}\text { Elemental analysis } \\
(\% \text { wt. dry basis })\end{array}$ & & $\begin{array}{l}\text { Chemical structure } \\
(\% \text { wt. dry basis })\end{array}$ \\
\hline Volatile matter & 82.15 & Carbon & 48.35 & Cellulose & 40.4 \\
Ash & 1.07 & Hydrogen & 5.93 & Hemicellulose & 34.01 \\
Fixed carbon & 16.78 & Oxygen & 44.21 & Lignin & 10.13 \\
Moisture content $(\%$ wt.) & 10 & LHV $_{\text {daf }}\left(\mathrm{MJ} \mathrm{kg}^{-1}\right)$ & 18 & Ash & 1.27 \\
\hline
\end{tabular}

*Nitrogen composition is determined by the difference in the elemental analysis solar (5.3 MW), geothermal (2.2 GW) and biomass (15 GW) $[17,18]$. Most of this potential has been developed into hydropower large-scale plants, accounting now for $65.8 \%$ of total power generation [19], yet less than $1 \%$ of the country's installed generation capacity comes from other renewable sources, such as wind, biomass and solar [19]. A conservative estimate of the theoretical energy potential from biomass resource in Colombia is $744 \mathrm{PJ}$ per year, with the largest contribution coming from agricultural residues (53\%) and the second from animal waste (24\%) [20].

A more decentralized and source-diverse power generation infrastructure could enhance energy access in off-grid areas and help reduce power losses [21]. An example of this is the successful deployment of microgrids in remote rural areas, demonstrating a feasible solution for distributed generation schemes [22]. Additionally, recent policies, like the Law 1715 of 2014, that regulates the integration of renewable energies in the country [23], as well as the ongoing penetration of clean energy technologies, at lower costs [24], are setting the conditions to increase and diversify renewable energy sources in the national energy mix.

However, the integration of renewable technologies in Colombia still faces certain obstacle, such as: insufficient government incentives and a lack of awareness of the real resource potential for renewables [24] and of the feasibility for technologies deployment. Particularly, for power generation and combined heat and power generation (CHP), there is a deficiency of effective regulatory frameworks and pricing schemes, where the barrier is even larger for distributed generation and small-scale applications [25].

\subsection{Coffee residues utilization for bioenergy in Colombia}

Colombia is a typical coffee producer country with almost $70 \%$ of coffee cultivation taking place in small coffee plantations $(<5 \mathrm{ha})$, which are family owned and rely on coffee trading for their livelihood [26]. Coffee stems in Colombia represent a significant amount of biomass, reporting approximately $2,849,000 \mathrm{t}$ by 2010 . This corresponds to a theoretical energy potential of 38,561 TJ/year [27] that would equate approximately $17 \%$ of the total power generation in Colombia by 2016 [19]. The stems are collected after coffee- tree prunings and, like other agricultural residues, are often burned inefficiently as fuel in traditional cookstoves or in open fields of rural areas [10].

The untapped energy potential of coffee crop residues in Colombia has been the focus of recent research, such as that by Garcia et al. [16], Garcia et al. [28] and Oliveros-Tascón et al. [29]. Certain aspects, however, have not been fully considered, such as the potential to integrate the recovered waste heat into the coffee processing chain and the analysis of the energy demand and residual biomass availability within coffee farms in Colombia. This paper addresses these aspects by carrying out a comprehensive modelling of the whole system (i.e. including the biomass pre-treatment and gas conditioning), which enables the identification of process heat integration opportunities. Additionally, this study analyzes the energy demand and biomass supply relationship of the coffee sector, to identify at which scale these systems could be potentially deployed.

This paper contributes to the resource awareness by linking the locally available resource potential of coffee stems to the existing local energy demand of the coffee sector. It also enhances the understanding of how biomass residues could be practically converted to generate sustainable power and heat vectors in coffee farms through small-scale gasification systems coupled with internal combustion engines (ICE). This is achieved by an evaluation of the coffee stem-based product gas composition and low heating value (LHV) to determine its feasibility as a gas fuel for ICE and/or CHPs, using a process modelling approach. This is followed by an assessment of the overall performance of the system by estimating the net power output, the maximum recoverable low-grade heat and the overall cogeneration system's efficiency. Finally, an analysis is conducted on the match between the biomass resource availability and the energy demand of the coffee sector.

\section{Materials and methods}

\subsection{Technology selection and modelling approach}

Gasification is an emerging, but promising technology that can provide greater efficiencies and improved economics, particularly at small-scale applications; as well as lower 
emissions, compared with other thermochemical conversion processes, like combustion [30, 31]. Particularly, studies on coffee stem conversions for bioenergy suggest that the gasification route has lower energy requirements and performs better for different potential environmental impacts [16].

This study applies a thermodynamic equilibrium model using the process modelling software, Aspen Plus V10. This model approach can provide an initial good estimation of the gas composition and yields, identify operating limits and allow the evaluation of the relationship between biomass characteristics and process parameters [32].

The following conditions and assumptions are considered for the process modelling: (i) the thermodynamic equilibrium model is based on the minimization of the Gibbs free energy approach to predict the gas composition and yield; (ii) the gasification process is modelled assuming that after a long residences time, the system reaches a steady state and reactants establish a chemical equilibrium [33], (iii) the gasifier is modelled as operating at atmospheric pressure; (iv) biomass particles have a uniform size after chipping; (v) tars are assumed as non-equilibrium products, hence tar formation is not modelled due to the limitations of the thermodynamic equilibrium approach; (vi) the biomass devolatilization phase (pyrolysis) occurs instantaneously and the main volatile gases produced are $\mathrm{H}_{2}, \mathrm{CO}, \mathrm{CO}_{2}, \mathrm{CH}_{4}$ and $\mathrm{H}_{2} \mathrm{O}$ treated as ideal gases; (vii) ash in biomass is assumed to be inert, i.e. it does not participate in the chemical reactions. These assumptions are consistent with other gasification modelling works, such as in [34-43].

\subsection{Biomass characteristics}

The proximate and elemental compositions of the coffee stems are taken from the work of Garcia et al. [16] and are presented in Table 2. Also from the same source, the particle size of the coffee stems, after chipping, is specified to $2 \mathrm{~cm}$.

\subsection{Downdraft gasifier}

The downdraft gasifier design is chosen for this study as it has featured as a simple design with well-proven performance and relatively low investment costs for small-scale applications [44]. In addition, because of their internal configuration, downdraft gasifiers generate a producer gas with low tar content and heating value suitable for use as fuel in ICEs for power generation $[45,46]$. Table 3 presents the gasifier design parameters and average operating conditions, used for Aspen plus simulations. The expected thermal power output of the gasifier $\left(100 \mathrm{~kW}_{\text {th }}\right)$ is set from examining the average electricity demand of a coffee farm and biomass availability. The biomass feed rate is determined from assuming a downdraft gasifier's efficiency of $75 \%$ that falls within the range for this type of gasifiers $[34,47]$.
Table 3 Gasifier design parameters and operating conditions

\begin{tabular}{ll}
\hline Design/operation parameters & Value \\
\hline Gasifier thermal power output & $100 \mathrm{~kW}_{\text {th }}$ \\
Gasifier's efficiency (initial estimation) & $75 \%$ \\
Biomass feed rate & $26-28 \mathrm{~kg} \mathrm{~h}^{-1}$ \\
Equivalence ratio (ER) & 0.3 \\
Air mass flow & $42 \mathrm{~kg} \mathrm{~h}^{-1}$ \\
Operating pressure & Atmospheric \\
\hline
\end{tabular}

\subsection{Aspen modelling and simulation procedure}

A small-scale 100-kW $\mathrm{k}_{\text {th }}$ downdraft gasification plant, including the upstream biomass chipping and downstream gas cleanup stages, is simulated using Aspen Plus V10 software to predict the product gas composition, yield and gasification temperature. Validation of the simulation results for the product gas composition and heating value is made against the experimental results of Garcia et al. [16] and Oliveros-Tascón et al. [29].

Figure 1 shows the Aspen gasification process flow diagram. The model represents two core stages: the biomass preparation stage (i.e. chipping) and the gasification stage. The gas cleanup and cooling stages, together with the producer gas combustion for power generation are presented later in this section.

The biomass preparation stage starts with the coffee stem drying through sun-air-drying exposure during 1 month to reduce the moisture contents from $63-70$ to $10-20 \% \mathrm{wt}$., as reported by [29]. This natural drying of the biomass could be possible due to the poor hygroscopic characteristics of the coffee stems and the weather conditions in the Colombian coffee regions, as indicated in [48]. Next, the coffee stems are cut in a wood chipper (approximate throughput of 0.75 ton $\mathrm{h}^{-1}$ ) to achieve an average uniform chip size of $2 \mathrm{~cm}$, following specifications presented by [29].

The gasification stage itself comprises three steps representing the main phases inside a real downdraft gasifier operation. Figure 2 schematises the simulation procedure followed by Aspen Plus for these stages.

In the first step (biomass drying), the biomass moisture content is reduced up to the level required for downdraft gasifiers $(<10 \% \mathrm{MC})$ [46] using stoichiometric-based reactor (RSTOIC), assuming that previously the coffee stems have been exposed to sun drying to reduce its moisture content from 25 to $10-15 \%$ wt. [29]. During the devolatilization step, the dry biomass breaks down into its constituent elements $(\mathrm{C}$, $\mathrm{H}, \mathrm{O}, \mathrm{N}$ and $\mathrm{S}$ ) in the absence of air, with a reactor based on specific yields (RYIELD). The last step, the partial combustion and gasification zone, is modelled using a Gibbs reactor block (RGIBBS), which follows the Gibbs free energy minimization approach. At this stage, air acting as the gasifying agent enters the reactor with the flow rate determined by the equivalence ratio specified in Table 3 . A cyclone unit block 
Fig. 1 Aspen Plus process flowsheet of the biomass gasification system

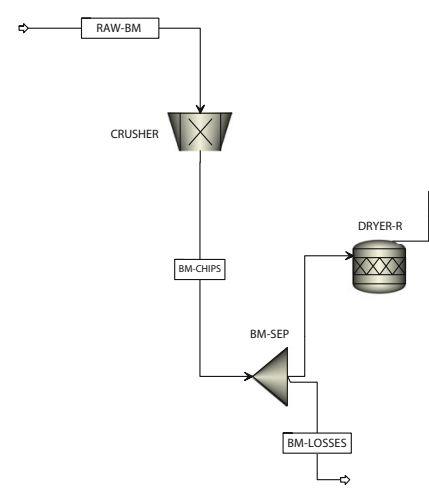

represents the separation of the gas from ash and char (as solid particles).

\subsection{Model validation with experimental data}

The gasification model is validated by comparing the predicted values of the gas composition, yield and LHV against the experimental data reported by Garcia et al. [16]. A second dataset reported by Oliveros-Tascón et al. [29], from Cenicafe (Colombian Coffee Research Centre) is used also for the validation. For each case, the Aspen Plus gasification model reproduced a minimum of input conditions of the original experiments, such as the biomass ultimate and proximate composition, biomass feed rate and equivalence ratio.

This experimental dataset was used to validate the model as it reports biomass properties of coffee stem indigenous from Colombia and the composition of the producer gas resulting from coffee stem gasification in downdraft gasifiers. This fits well with the Colombian study case and the smallscale bioenergy application of this research.

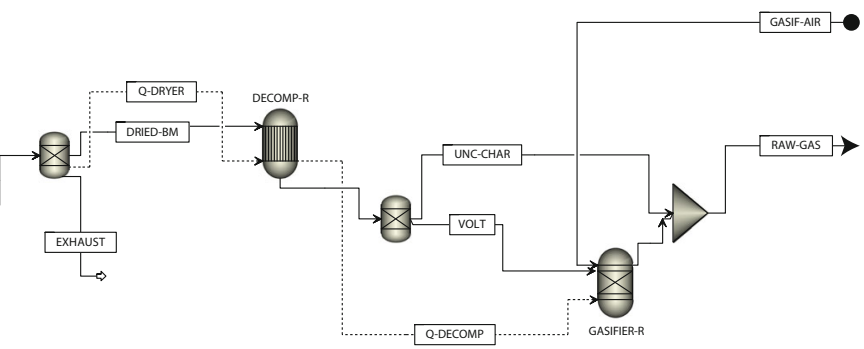

COMBUSTION
CALCULATOR

\subsection{Sensitivity analysis}

A sensitivity analysis is carried out in Aspen Plus to study the effect of governing gasification parameters on the producer gas composition and the gas heating value. The parameters are the biomass moisture content (MC), the equivalence ratio (ER) and the air preheating temperature. The MC is one of the most challenging biomass properties in the performance of thermochemical processes. For this study, MC values are set between 10 and $60 \%$ wt., typical of woody biomass compositions [49]. The ER also affects greatly the gasifier performance, determining the gasification temperature and having a great influence on the final gas composition and heating value. The ER is varied within realistic gasification conditions, between 0.1 and 0.5 . Lastly, the purpose of evaluating the temperature of the gasifying air is to analyze the positive effect that the air preheating can have on the gasification conversion efficiency by increasing the concentration of the combustible gases $\left(\mathrm{CO}\right.$ and $\left.\mathrm{H}_{2}\right)$, therefore increasing the gas $\mathrm{HV}$ [42]. The air preheating temperatures range between 25 and $500{ }^{\circ} \mathrm{C}$.
Fig. 2 Aspen Plus simulation procedure for biomass gasification model

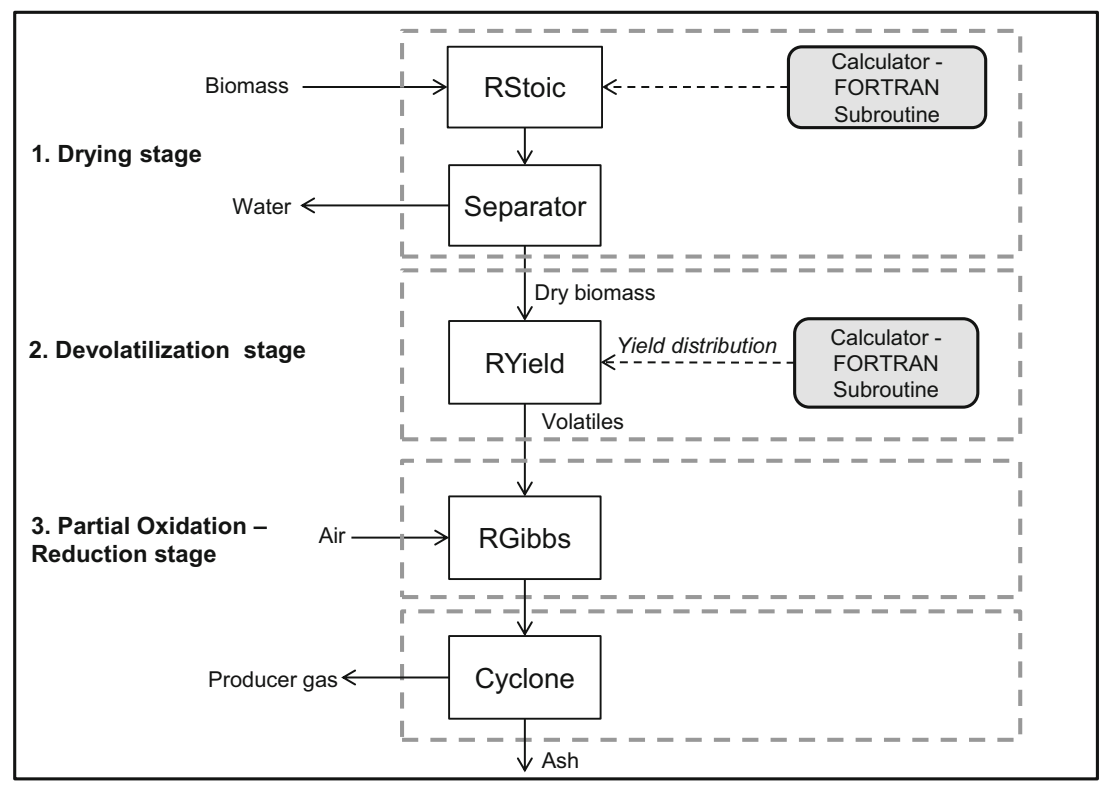




\subsection{Tar concentration in the producer gas}

The presence of tar in the syngas is a significant problem of operability for many gasifiers. Therefore, certain measures are proposed to minimize potential fouling of downstream equipment due to tar concentration:

1. Selection of a downdraft gasifier. This technology produces a gas with low tar concentration $(0.015-$ $0.5 \mathrm{~g} \mathrm{Nm}^{-3}$ ) suitable to operate coupled to internal combustion engines $[45,46]$.

2. Selection and preliminary design of the cold gas cleanup system to reduce the remaining tar and particle concentration in the producer gas. This configuration has proven to be reliable and highly efficient for small-scale fixed bed gasifiers [50, 51].

3. The preheating of the gasifying air to increase the temperature in the gasifier enhances the effectiveness of tar cracking, in addition to increasing the LHV of the producer gas [52].

4. Assumption of a relatively low capacity factor (30-35\%) for small-scale bioenergy application, allowing for manual cleaning and removal of tar deposits (if required) during shutdowns of the gasifier.

\subsection{Gas cleanup system description}

The selection of the producer gas cleaning system depends on the level and type of contaminants in the producer gas, as well as in the end-use application [50, 51, 53]. For ICE applications, it is important that the producer gas meets the fuel quality requirements of particulates concentration $\left(<0.05 \mathrm{~g} \mathrm{Nm}^{-3}\right)$ and tar content $\left(<0.100 \mathrm{~g} \mathrm{Nm}^{-3}\right)$, to avoid severe engine operational problems $[50]$.

The cold gas cleanup configuration, suitable for gas temperatures below $400{ }^{\circ} \mathrm{C}$ [51], was adopted for this study. This selection was made considering the small-scale application of the system and the characteristics of a producer gas generated in a downdraft gasifier: temperature of $\sim 400{ }^{\circ} \mathrm{C}$ (after the gas cooling stage) and an expected low tar content concentration $\left(0.015-0.5 \mathrm{~g} \mathrm{Nm}^{-3}\right)[54,55]$. Cold gas cleanup systems have proven to be reliable and highly efficient for gasification systems, at the expense of thermal penalties from cooling the producer gas and increasing operation costs from an effluent treatment plant [51].

\subsubsection{Cold gas cleanup preliminary design}

The cold gas cleanup configuration proposed in this work comprises a cyclone, venturi scrubber and a set of fabric filters. The producer gas exiting the gasifier at temperature $651^{\circ} \mathrm{C}$ enters the cyclone separator to remove particulates of $d>10 \mu \mathrm{m}$ size with a removal efficiency of $85-95 \%[50,56]$. The entrance diameter of the cyclone is calculated using the gas volumetric flow and an optimum gas inlet velocity of $15 \mathrm{~m} \mathrm{~s}^{-1}$. The other dimensions of the cyclone are determined as a function of this diameter, following the dimensions of Stairmand high-efficiency cyclones [56].

After passing through the cooling stage, the producer gas enters the venturi scrubber where water is supplied into the venturi throat to capture smaller particulates $(d>0.5 \mu \mathrm{m})$ and tars. At this stage, the gas temperature is reduced to $40.4{ }^{\circ} \mathrm{C}$. The water flow required as input into the scrubber is calculated using the gas volumetric flow and the optimum liquid-togas ratio $\left(1 \mathrm{~m}^{3}\right.$ per $\left.1000 \mathrm{~m}^{3}\right)$ for venturi scrubbers. The liquid effluent is treated in a water treatment plant which is also commonly required in a coffee processing plant. Lastly, the producer gas enters a demister to remove the condensed water and then passes through a fabric bag filter that complements the gas cleaning by removing particulates of $(d>0.2 \mu \mathrm{m})$ and tar, before it enters the engine.

Table 4 collates the main design factors and process parameters of the cold gas cleanup system of the gasification plant. More details on the methods for sizing the gas cleaning components are found in Perry et al. [57] and Sinnot [56].

\subsection{Cooling stages of the producer gas and flue gas}

Gas cooling stages are used to reduce the temperature of the producer gas and flue gas in order to meet process requirements. The low-grade heat recovered from these stages can potentially supply the internal and/or external heat energy demands. Particularly, for biomass small-scale applications, where the electrical efficiencies are low, a maximization of on-site heat utilization is essential to achieve higher energy efficiency and economic profitability [58].

In this gasification-ICE system, as Fig. 3 illustrates, the cooling stages consist of, first, two consecutive gas-air heat exchangers to cool down the producer gas, and a second heat exchanger unit to reduce the temperature of the flue gas, after the combustion of the clean producer gas in the ICE. The first cooling stage reduces the temperature of the producer gas to meet temperature specifications of the gas cleanup equipment and gas engine. The first heat exchanger (PGAS-HX1) cools down the producer gas from 792 to $699{ }^{\circ} \mathrm{C}$ and this sensible heat is used to preheat the gasifying air up to $250{ }^{\circ} \mathrm{C}$. The second heat exchanger (PGAS-HX2) continues decreasing the producer gas temperature to $120{ }^{\circ} \mathrm{C}$. The recovered heat duty is used to heat up an airstream with a potential application in the coffee bean drying stage. The airflow rate is set to $31 \mathrm{~m}^{3} \mathrm{~min}^{-1}$ to obtain an air temperature between 48 and $50{ }^{\circ} \mathrm{C}$, following optimum operating parameters in stationary coffee air-dryers [59]. Considering similar applications of gas cooling systems in small-scale gasification plants, the shell- 
Table 4 Process parameters for cold gas cleanup system $(d=$ particle diameter)

\begin{tabular}{lll}
\hline Plant unit & Design-process parameters & Value \\
\hline Cyclone separator & Gas volume flow & $260 \mathrm{~m}^{3} \mathrm{~h}^{-1}$ \\
& Optimum gas inlet velocity & $15 \mathrm{~m} \mathrm{~s}^{-1}$ \\
& Entrance cyclone diameter & $\mathrm{Dc}=0.218 \mathrm{~m}$ \\
& Removal efficiency & Particle separation $85-95 \%(d>10 \mu \mathrm{m})$ \\
Venturi water scrubber & Tar separation $60 \%[50]$ \\
& Gas volume flow & $95.7 \mathrm{~m}^{3} \mathrm{~h}^{-1}$ \\
& Liquid-to-gas ratio & $1 \mathrm{~m}^{3} \mathrm{per}^{3} 100 \mathrm{~m}^{3}$ (optimum design rate [57]) \\
& Liquid volume flow & $0.092 \mathrm{~m}^{3} \mathrm{~h}^{-1}$ \\
$T_{\text {in }} / T_{\text {out }}$ of producer gas & $110{ }^{\circ} \mathrm{C} / 40^{\circ} \mathrm{C}$ \\
Removal efficiency & Particle separation $99 \%(d>0.5 \mu \mathrm{m})$ \\
& & Tar reduction range $50-90 \%[50]$ \\
& Operation temperature & $40{ }^{\circ} \mathrm{C}$ \\
& Removal efficiency & Particle separation $99 \%(d>0.2 \mu \mathrm{m})[56]$ \\
& Tar reduction $70 \%$ \\
\hline
\end{tabular}

tube heat exchanger configuration using stainless steel tubes could be suitable in this case.

The second stage water cools the flue gas from the producer gas combustion with a concentric tubes heat exchanger (FGAS-HX) to a temperature of $120{ }^{\circ} \mathrm{C}$, in order to meet environmental regulations regarding airborne emissions [60] and prevent corrosive effects from condensation in the exhaust piping. The hot water is used in a second concentric tubes heat exchanger (AIR-HX) to heat up an airstream for the coffee drying process, following the parameters described above. A suitable material for these heat exchangers is steel, considering the water temperatures could be maintained below the boiling point.

Both heat exchanging stages are simulated with Aspen Plus to estimate the maximum recoverable heat duty for each cooling stage. This heat exchanger configuration for downdraft gasifiers plants is supported on the work of Raman et al. [52].

\subsection{Internal combustion engine specifications and producer gas combustion modelling}

Small-scale internal combustion engines are a technically and economically feasible option for distributed energy generation providing low capital costs, reliability, high operating efficiency, modularity and safety in comparison with other combustion technologies [61]. Producer gas with calorific values $\left(>4 \mathrm{MJ} \mathrm{Nm}^{-3}\right.$ ) and low pollutant contents (< $100 \mathrm{mg} \mathrm{Nm}^{-3}$ for tar content and $<50 \mathrm{mg} \mathrm{Nm}^{-3}$ for particulates) can be directly injected into ICE $[61,62]$. Spark ignition engines currently designed to work with petrol or diesel require adaptations in the injection systems to be fuelled with producer gas $[62,63]$; however, these do not affect performance at the level being assessed in this work.

For this study, a four-cylinder sparked fired engine with a continuous power rating of $25 \mathrm{~kW}_{\mathrm{e}}$ is selected for the electricity generation, using the specifications of a commercial engine-generator unit that functions coupled to a biomass downdraft gasifier [64]. The combustion phase of the engine is simulated through Aspen Plus, following a Gibbs minimization approach, to calculate the flue gas composition and temperature when the system reaches chemical and phase equilibrium. The outlet temperature of the exhaust gases sets the maximum thermal energy recovery from the flue gases. The mechanical system of the engine was not modelled, instead, an electrical efficiency of $30 \%$ is assumed to calculate the gross electrical power output of the system. An additional $20 \%$ of power derating is considered since fuelling the engine with the producer gas causes a lower net calorific value of the fuel mixture [65].

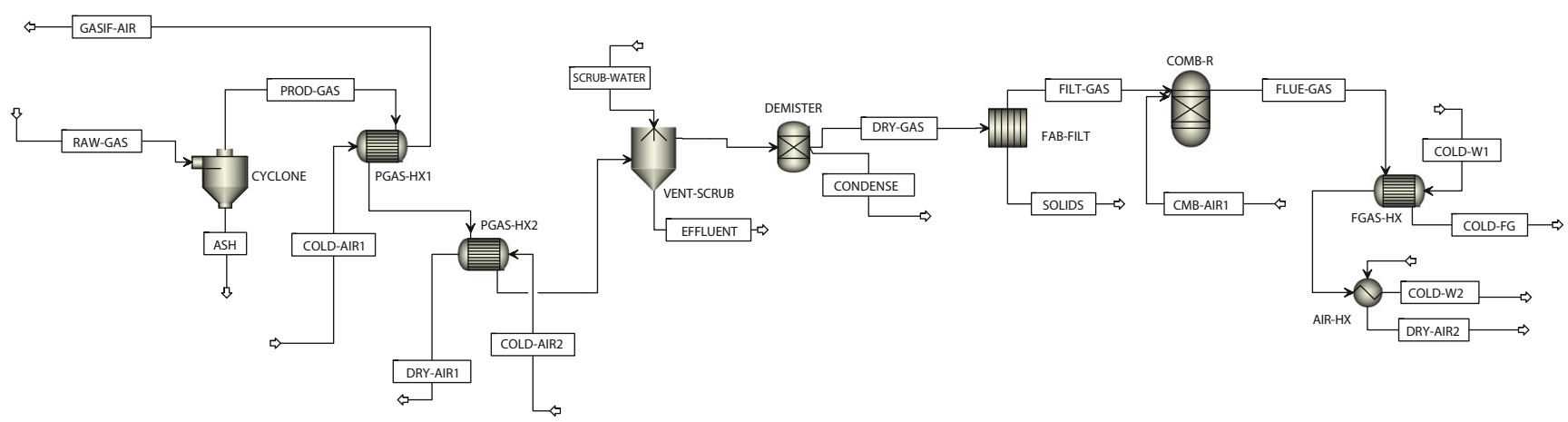

Fig. 3 Process flow diagram of gas cleanup gas cooling sub-system coupled to ICE unit 


\subsection{Gasification and overall system performance}

The technical performance of the gasification system is measured using the parameters, cold gas efficiency and hot gas efficiency; the whole system performance, comprising power generation and heat recovery, is measured using the cogeneration system efficiency. Table 5 describes these parameters.

\section{Results and discussions}

\subsection{Performance of the coffee stem gasification model}

Table 6 collates an overview of the most representative performance parameters of the gasifier-ICE system. The results show that the $100-\mathrm{kW}_{\text {th }}$ downdraft gasifier coupled to an ICE and fed with $27.2 \mathrm{~kg} \mathrm{~h}^{-1}$ of coffee stems produces a fuel gas that meets the minimun standards of $\operatorname{LHV}\left(4 \mathrm{MJ} \mathrm{Nm}^{-3}\right)$ for ICE applications. The utilisation of the producer gas in the ICE could generate $20.4 \mathrm{~kW}_{\mathrm{el}}$ of net electricity and $40.4 \mathrm{~kW}_{\text {th }}$ of thermal power output from the heat recovery stages.

The gasification performance parameters, cold gas efficiency (CGE) and hot gas efficiency (HGE) show a good conversion efficiency of the gasifier when using coffee stems as feedstock, both ranging within the characteristic numbers for downdraft gasifiers, CGE 30-60\% [54] and HGE 85-90\% [46].

\subsection{Model validation with experimental results}

Table 7 presents the validation of the Aspen simulation results with the experimental data on the producer gas composition, LHV and gas yield reported by Garcia et al. [16] referred to it as "Exp data 1" and the second dataset of experimental results by Oliveros-Tascón et al. [29] referred to it as "Exp data 2".

The simulation results show good agreement with the set of experimental data for the mole fractions of $\mathrm{H}_{2}, \mathrm{CO}, \mathrm{CO}_{2}$, and $\mathrm{N}_{2}$ gas species, the producer gas yield and the gas LHV. Nonetheless, the methane $\left(\mathrm{CH}_{4}\right)$ mole fraction is underpredicted by the simulation resulting in a high percentage error, for both cases. On this issue, the methane composition is usually under-predicted when a gasification system is modelled following a thermodynamic equilibrium approach. As theory specifies, the methanation reaction, described by the equation $\left(\mathrm{C}+2 \mathrm{H}_{2} \leftrightarrow\right.$ $\mathrm{CH}_{4}$ ), tends to deviate from chemical equilibrium at high temperatures (above $800^{\circ} \mathrm{C}$ ) [67], as is the case of for gasification.

On balance, since the $\mathrm{H}_{2}$ and $\mathrm{CO}$ composition are the main combustible components in the producer and are slightly overpredicted in the simulations, the low heating value is not deleteriously affected by the lower $\mathrm{CH}_{4}$ concentration. As a result, the producer gas LHV derives into an average percentage error of $13 \%$, acceptable for the purposes of this modelling work.

\subsection{Sensitivity analysis}

The effect of key gasification parameters on the gas temperature and composition, and consequently, on the gas low heating value and cold gas efficiency (CGE) of the gasifier is evaluated in this section. These results inform on the feasibility of practical implementation where feedstock properties may vary and operating parameters could be controlled to improve the gasifier performance.

\subsubsection{Effect of biomass moisture content}

Figure 4 illustrates the effect of the coffee stem moisture content (MC) on the gas composition and gasification

Table 5 Gasification efficiency and cogeneration system efficiency

\begin{tabular}{|c|c|}
\hline Parameter & Definition and formula \\
\hline Cold gas efficiency & $\begin{array}{l}\text { Measures the potential energy output of the producer gas over the biomass energy input [46]: } \\
\mathbf{C G E}=\frac{\boldsymbol{m}_{\mathrm{pg}} \cdot \mathbf{L H V} \mathbf{v}_{\mathrm{pg}}}{\boldsymbol{m}_{\mathrm{bm}} \cdot \mathbf{L H} \mathbf{V}_{\mathbf{b m}}} \\
\text { where } m_{\mathrm{pg}} \text { and } \mathrm{LHV}_{\mathrm{pg}} \text { are the mass and low heating value of the product gas and } m_{b m} \text { and LHV } \\
\text { heating value of the biomass feed }\end{array}$ \\
\hline Hot gas efficiency & $\begin{array}{l}\text { Measure, in addition to the CGE, HGE includes the sensible heat carried by the hot gas [46]: } \\
\mathbf{H G E}=\frac{\boldsymbol{m}_{\mathbf{p g}} \cdot \mathbf{L} \mathbf{H} \mathbf{V}_{\mathbf{p g}}+\boldsymbol{m}_{\mathbf{p g}} \cdot \boldsymbol{C}_{\mathbf{p}} \cdot\left(\boldsymbol{T}_{\mathbf{f}}-\boldsymbol{T}_{\mathbf{0}}\right)}{\boldsymbol{m}_{\mathbf{b m}} \cdot \mathbf{L} \mathbf{H} \mathbf{V}_{\mathbf{b m}}} \\
\text { where } T_{\mathrm{f}} \text { is the gas temperature at the gasifier exit, } T_{0} \text { is the temperature of the fuel entering the gasifier and } C_{\mathrm{p}} \text { is the heat } \\
\quad \text { capacity of the product gas }\end{array}$ \\
\hline $\begin{array}{l}\text { Cogeneration system } \\
\text { efficiency }\end{array}$ & $\begin{array}{l}\text { Measures the ratio between the sum of the net electric power output }\left(E_{\mathrm{el}}\right) \text { and useful thermal power output }\left(E_{\mathrm{th}}\right) \text { over the } \\
\text { biomass energy input }\left(E_{\mathrm{bm}}\right)[63] \\
\boldsymbol{\eta}_{\mathbf{c o g e n}}=\frac{\boldsymbol{E}_{\mathrm{el}}+\boldsymbol{E}_{\mathrm{th}}}{\boldsymbol{E}_{\mathrm{bm}}} \text {, where } E_{\mathrm{bm}}=m_{\mathrm{bm}} . \mathrm{LHV}_{\mathrm{bm}}\end{array}$ \\
\hline
\end{tabular}


Table 6 Downdraft gasifier-ICE system performance parameters

Gasifier-ICE system performance parameters

\begin{tabular}{ll}
\hline Clean producer gas flow & $85 \mathrm{Nm}^{3} \mathrm{~h}^{-1}\left(64 \mathrm{~kg} \mathrm{~h}^{-1}\right)$ \\
Gas yield & $2.46-\mathrm{kg}_{\text {gas }}$ per kg biomass \\
Producer gas calorific value & $5.6 \mathrm{MJ} \mathrm{Nm}{ }^{-3}\left(5.3 \mathrm{MJ} \mathrm{kg}^{-1}\right)$ \\
Cold gas efficiency (CGE) & $70.6 \%$ \\
Hot gas efficiency (HGE) & $87.2 \%$ \\
Net electricity output & $20.4 \mathrm{~kW}_{\mathrm{e}}$ \\
Low-grade heat recovery & $40.4 \mathrm{~kW}_{\mathrm{th}}$ \\
Cogeneration system efficiency & $45.6 \%$ \\
\hline
\end{tabular}

temperature profile. The $\mathrm{H}_{2} \mathrm{O}$ concentration in producer gas increases steadily over the biomass moisture content range. The excess of $\mathrm{H}_{2} \mathrm{O}$ demands more energy to evaporate the moisture in the biomass, plunging the gasification temperature. A decline in the temperature favours the inverse direction of the endothermic water-gas reaction and the forward direction of the exothermic $\mathrm{CO}$ shift reaction. This results in a sharp drop in the $\mathrm{CO}$ concentration and a gradual decrease in $\mathrm{H}_{2}$ concentration for $\mathrm{MC}$ values above $25 \%$. On the contrary, the $\mathrm{CO}_{2}$ mole fraction increases slowly up to an $\mathrm{MC}$ of $35 \%$, after it starts to stabilize. The methane concentration is very low and slowly decreases with higher moisture contents.

Figure 5 presents the overall effect of the moisture content on the gas LHV and CGE. The decreasing concentration of $\mathrm{H}_{2}$ and $\mathrm{CO}$ and rising mole fraction of $\mathrm{H}_{2} \mathrm{O}$ in the producer gas lower the gas LHV, which consequently, affect the gasifier performance, measured by the CGE of the gasifier. This confirms the importance of controlling the moisture content of the biomass, which for downdraft gasifiers should not exceed $25 \%$ wt. [46, 55], keeping MC ranges between 10 and 20\% wt. for better performance [32].

\subsubsection{Effect of the equivalence ratio}

In authothermal gasifiers, as the one modelled in this work, the gasification temperature can be controlled with the amount of air supplied to the gasifier. Figure 6 illustrates this relation, as the ER increases, the gasification temperature rises favouring the products of the endothermic water-gas reaction $(\mathrm{C}+$ $\mathrm{H}_{2} \mathrm{O} \leftrightarrow \mathrm{CO}+\mathrm{H}_{2}$ ). The mole fractions of $\mathrm{CO}$ and $\mathrm{H}_{2}$ rise as $\mathrm{ER}$ increases, both reaching peak values at $\mathrm{ER}=0.25$. At this equivalence ratio, downdraft gasifiers are expected to give the best gas yield [46], as shows the trend of the $\mathrm{CO}$ and $\mathrm{H}_{2}$ mole fractions.

In contrast, the $\mathrm{CO}_{2}$ and $\mathrm{H}_{2} \mathrm{O}$ mole fractions drop between ER values of 0.25 and 0.35 , respectively, after which they start increasing gradually. As more $\mathrm{O}_{2}$ is available in the gasifier and the carbon in the biomass has been consumed, the $\mathrm{CO}$ and $\mathrm{H}_{2}$ start reacting with the oxygen, producing the combustion products $\mathrm{CO}_{2}$ and $\mathrm{H}_{2} \mathrm{O}$. The $\mathrm{CH}_{4}$ mole fraction decreases until almost zero, due to methanation reaction tending towards more reactants than products when the temperature rises.

The concentration of the producer gas combustible components $\mathrm{CO}$ and $\mathrm{H}_{2}$ determine the gas low heating value, and consequently, the cold gas efficiency of the gasification system. Figure 7 shows that as ER increases from 0.1 to 0.25 , the gas LHV goes up gradually, reaches a peak when the $\mathrm{CO}$ and $\mathrm{H}_{2}$ mole fractions are in their maximum values and then falls rapidly as the concentrations of $\mathrm{CO}$ and $\mathrm{H}_{2}$ drop. Consequently, the cold gas efficiency (CGE) follows a similar trend, where the highest CGE yields at an ER value of 0.25.

\subsubsection{Effect of air preheating}

Air entering the gasifier as the gasifying agent at temperatures higher than ambient temperatures $\left(>25^{\circ} \mathrm{C}\right)$ can improve the gasification conversion efficiency. Figures 8 and 9 show how as the air temperature increases the $\mathrm{H}_{2}$ and $\mathrm{CO}$ mole fractions

Table 7 Validation of Aspen simulation results with experimental data

\begin{tabular}{|c|c|c|c|c|c|c|}
\hline \multirow[t]{2}{*}{ Gas species } & \multicolumn{3}{|c|}{ Producer gas parameters: simulation vs. experimental data 1} & \multicolumn{3}{|c|}{ Producer gas parameters: simulation vs. experimental data 2} \\
\hline & Sim. data $1($ mole $\%)$ & Exp. data $1($ mole $\%)$ & Difference & Sim. data 2 (mole \%) & Exp. data 2 (mole \%) & Difference \\
\hline Hydrogen & $22.3 \%$ & $19.53 \%$ & 2.77 & $20.4 \%$ & $19.9 \%$ & 0.5 \\
\hline Carbon monoxide & $18.8 \%$ & $16.32 \%$ & 2.48 & $19.8 \%$ & $19 \%$ & 0.8 \\
\hline Carbon dioxide & $13.8 \%$ & $13.77 \%$ & 0.03 & $11.5 \%$ & $10 \%$ & 1.5 \\
\hline Methane & $1.2 \%$ & $3.42 \%$ & 2.22 & $0.65 \%$ & $3 \%$ & 2.35 \\
\hline Nitrogen & $43.4 \%$ & $46.49 \%$ & 3.09 & $41 \%$ & $\mathrm{n} / \mathrm{a}$ & - \\
\hline $\operatorname{LHV}_{\text {d.b. }}$ & $4.7 \mathrm{MJ} / \mathrm{kg}$ & $4 \mathrm{MJ} / \mathrm{kg}$ & 0.7 & $4.9 \mathrm{MJ} / \mathrm{m}^{3}$ & $5.6 \mathrm{MJ} / \mathrm{m}^{3}$ & 0.7 \\
\hline Gas yield & $2.52 \mathrm{~kg}$ gas $/ \mathrm{kg}$ biomass & $2.84 \mathrm{~kg}$ gas $/ \mathrm{kg}$ biomass & 0.32 & $2.54 \mathrm{~kg}$ gas $/ \mathrm{kg}$ biomass & $2.12 \mathrm{~kg}$ gas $/ \mathrm{kg}$ biomass & 0.54 \\
\hline
\end{tabular}

d.b., dry basis; $n / a$, not available 
Fig. 4 Effect of biomass moisture content on the producer gas composition and gasification temperature

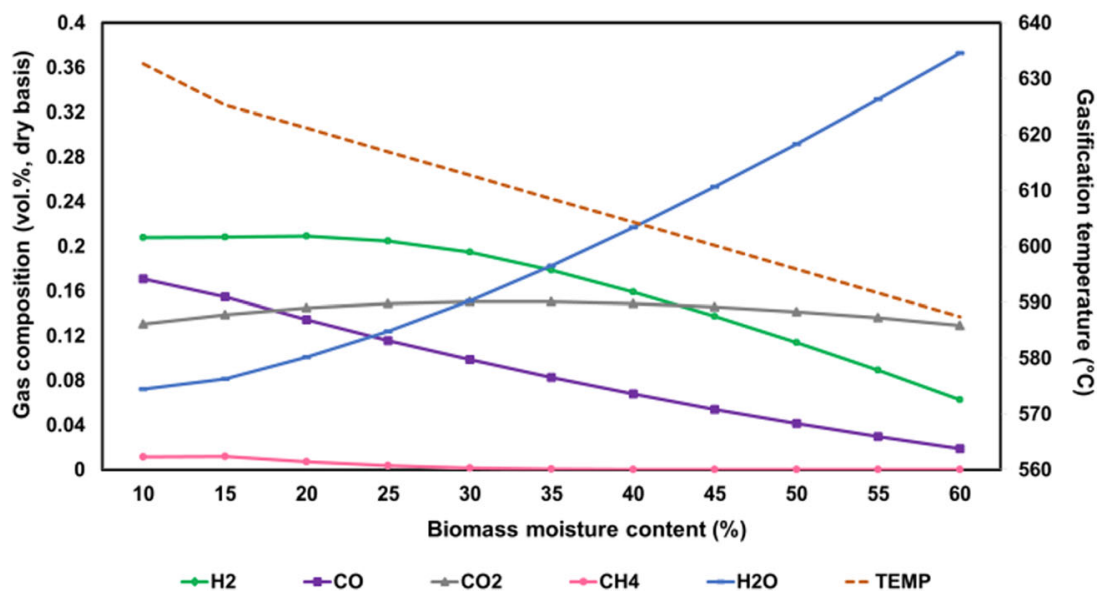

augment, resulting in a higher gas LHV. Opposed to this, the $\mathrm{CO}_{2}$ and $\mathrm{H}_{2} \mathrm{O}$ mole fractions decrease. The $\mathrm{CH}_{4}$ mole fraction remains almost constant across the whole range. This behaviour is caused by an increase in the gasification temperature due to the higher sensible heat of the air stream.

The trends followed by the producer gas composition and heating value, when varying the above key parameters, show the expected behaviour, also in accordance with previous studies, like Ramzan et al. [40]; Zainal et al. [68]; Doherty et al. [42], Yao et al. [69] and Altafini et al. [70]. The results of the sensitivity analysis also support the predictive capability and robustness of the model to variations in the producer gas composition.

\subsection{Heat recovery pathways}

The main characteristics of the two heat recycling systems, from the producer gas and flue gas cooling stages, of the coffee stem gasification-ICE systems are presented in Table 8. A higher thermal energy stream is attainable when cooling down the flue gases in the second heat recovery stage, due to a higher mass flow rate of the flue gases. For the baseline setting ( $20 \mathrm{~kW}_{\mathrm{e}}$ of net power output), the total maximum heat duty that could be recovered from the gas cooling stages is $40.4 \mathrm{~kW}_{\mathrm{th}}$. This results in a thermal power output efficiency of $30.3 \%$ for the whole system, with reference to the biomass energy input. The heat duty recovered from PGAS-HX1 $(2.69 \mathrm{~kW})$ could be utilized to heat the gasifying air up to $250{ }^{\circ} \mathrm{C}$, resulting in an increase in the LHV of the producer gas from to 4.7 to $5.3 \mathrm{MJ} \mathrm{kg}^{-1}$; another potential application is when the biomass requires external mechanical pre-drying before entering the gasifier. The heat recovered, in the form of a hot air stream from the PGAS-HX2, and AIR-HX could be used to supply totally or partially the process heat demand of the coffee mechanical drying.

Coffee drying is a key step in the grain processing, hence the importance of maintaining a uniform drying process to achieve a standard grain moisture content (10-12\% wt.) [59]. The optimum air temperature $\left(48-52{ }^{\circ} \mathrm{C}\right)$ and airflow rate $\left(66 \mathrm{~m}^{3} \mathrm{~min}^{-1}\right.$ per ton of coffee for static layers dryers) conditions, as established by Cenicafe in [59], are in theory achieved by combining both recovered heat duties.

\subsection{Energy balance}

The energy flows of the overall system are presented in Fig. 10, as a Sankey diagram to schematize the transformation
Fig. 5 Effect of biomass moisture content on the producer gas LHV (dry basis) and CGE

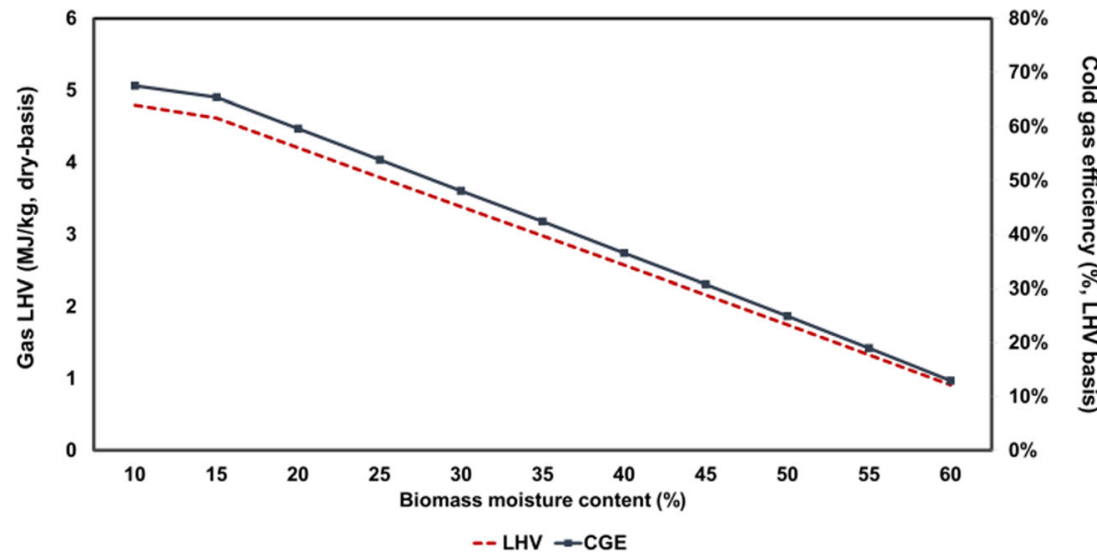


Fig. 6 Effect of equivalence ratio on the producer gas composition and gasification temperature

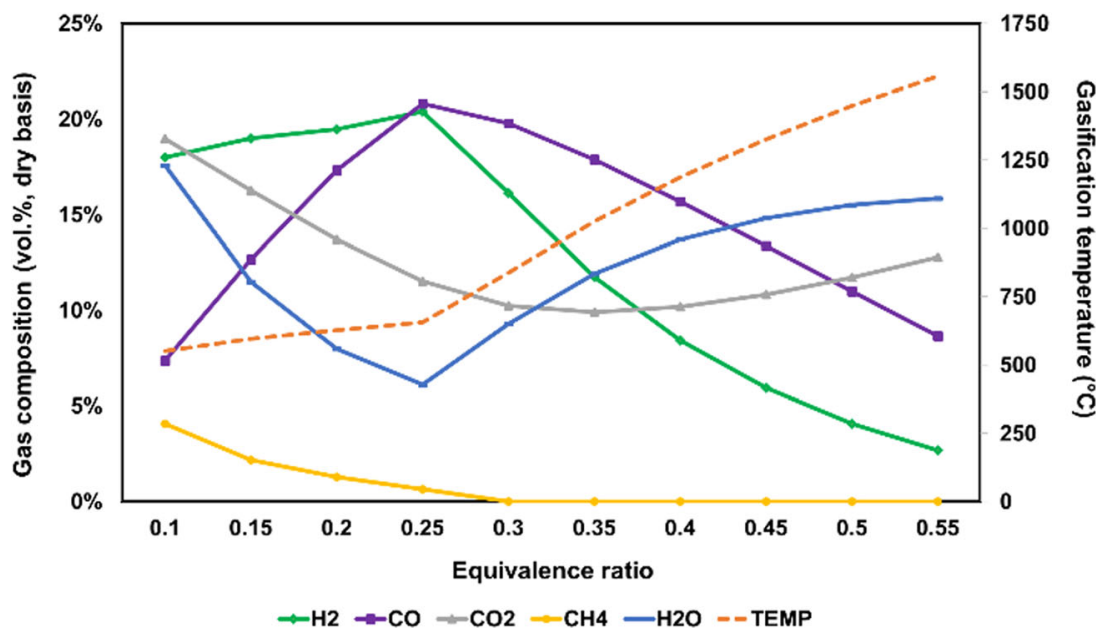

of the biomass energy input into useful energy outputs (power and low-grade heat), as well as to take into account the energy losses of the system. In the first stage, the intrinsic chemical energy of the biomass is transformed through gasification into the energy carried by the clean producer gas, with a $71 \%$ overall efficiency. A fraction of the raw producer gas thermal energy (13.7\%), in the form of sensible heat, is recovered as low-grade heat in the gas cooling stage. The energy losses in the gasifier and gas cleanup stage account for almost $15 \%$ of the biomass energy input.

In the second stage, the producer gas energy is converted into electrical power through the ICE generator set with an electrical efficiency of $24 \%$, where a fraction (10\%) of the gross electrical output is used to supply the internal plant's power demand resulting in a net power output of $20 \mathrm{~kW}_{\mathrm{e}}$. In addition, part of the sensible heat from the hot flue gases is recovered through a loop of heat exchangers. The heat energy losses coming from the power train section, ICE and the flue gas stream correspond to $52.6 \%$ of the producer gas energy input.

Overall, the cogeneration system efficiency, results in $45.6 \%$, agreeing with numbers reported in similar works about the gasification of agricultural residues in gasifiers-CHP systems $[63,71,72]$. The maximum low-grade heat recovered from both cooling systems could be used to supply the internal heat requirements of the system and/or external heat demands of the coffee drying process.

Furthermore, considering the significant thermal energy that the producer gas carries within, this gas could also be applied for direct utilization in boilers for on-site heat production. Even though this energy pathway is not studied here, it is pertinent to highlight the versatility of the producer gas as a fuel for small-scale bioenergy applications in rural areas.

\subsection{Biomass availability and energy demand of the Colombian coffee sector}

The electricity generated from this bioenergy system can be used to meet the electrical power demand of coffee farms or community coffee processing plants in rural areas. In addition, the low-grade heat recovered from the gas cooling phases can supply partially the process heat required for the coffee mechanical drying. Yet, for this to start materializing, the match
Fig. 7 Effect of equivalence ratio on the producer gas LHV (dry basis) and CGE

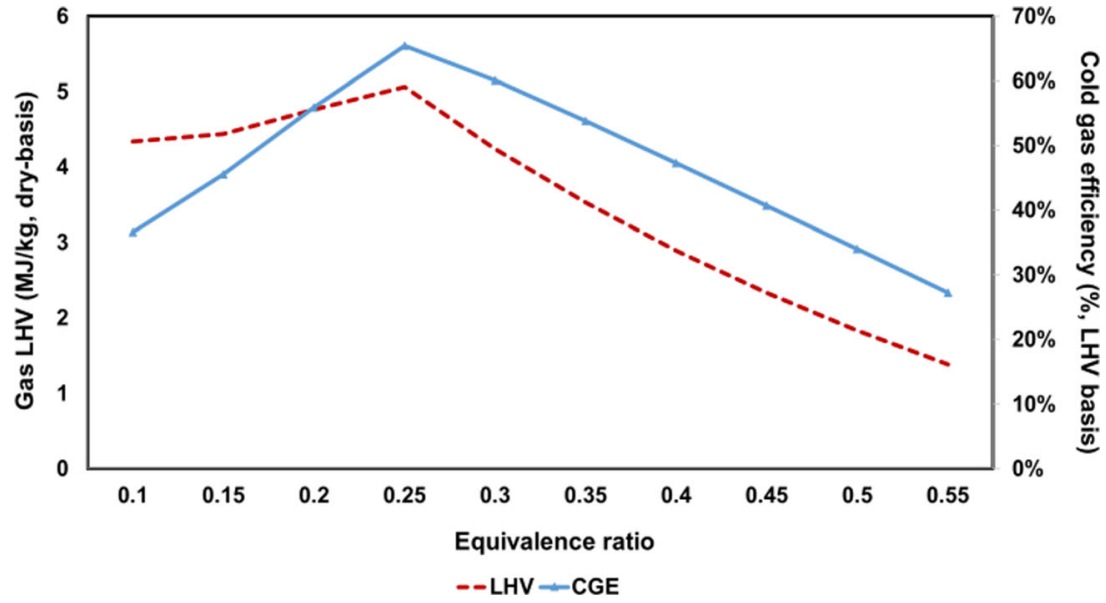


Fig. 8 Effect of gasifying air temperature on producer gas composition and gasification temperature

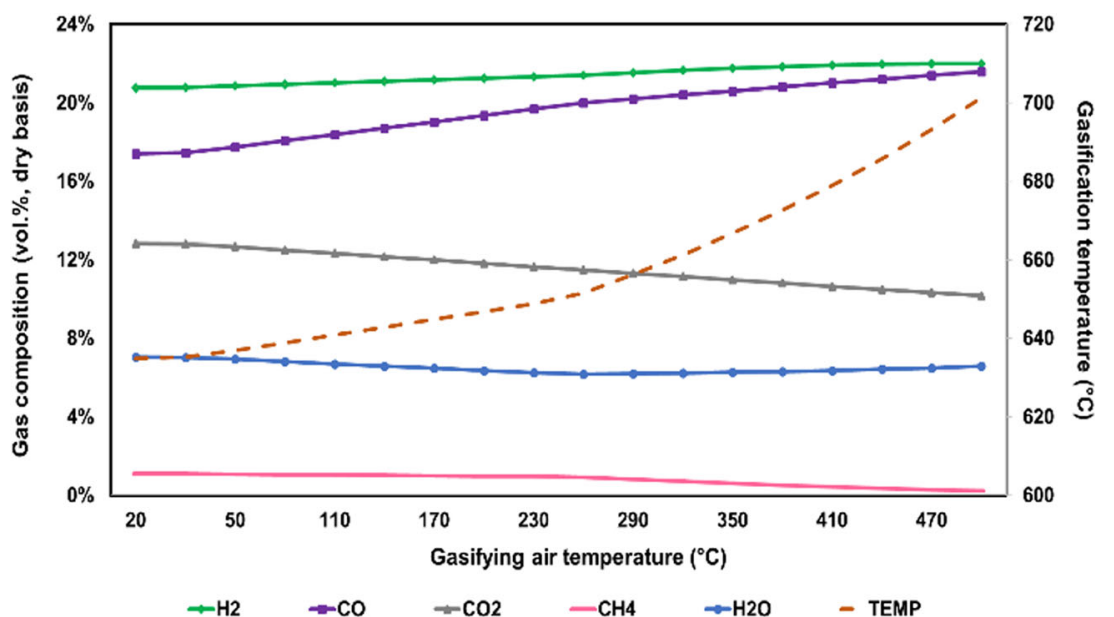

between the biomass resource availability and the farm's energy demand has to be considered.

During the coffee harvesting periods in Colombia, occurring twice a year, the operation of the $100 \mathrm{~kW}_{\text {th }}$ gasifier ICE for $336 \mathrm{~h}$ per month could result in a net electricity generation of $6720 \mathrm{kWh}$ per month and a maximum net thermal power output of $12,400 \mathrm{kWh}$ per month, ${ }^{1}$ requiring approximately 9 tons per month of coffee wood chips as fuel input to run. This net power output could meet the electricity monthly demand of two large-scale coffee farms (cultivated areas $\geq$ 10 ha) in Colombia, with similar coffee production and average electricity consumption of $2700 \mathrm{kWh}$ per month per farm [73]. This demand includes the power requirements of the farm household appliances and the coffee processing plant.

Medium (areas between 5 and 10 ha) to large (areas > 10 ha) scale farms with coffee processing plants that generally require mechanical drying [59] could benefit from part of the recovered heat of the system by transforming it in a hot air stream $\left(50^{\circ} \mathrm{C}\right)$ to dry up to 11 tons per month of washed coffee beans, assuming a thermal efficiency of $52 \%$ for a common coffee mechanical dryer [74]. As a result, this could provide 5 tons of green coffee per month ready for market trading.

Alternatively, this power and heat generation could also supply the power demand of a large community-based coffee processing plant, requiring on average $25 \mathrm{~kW}$ of power capacity for the processing equipment.

The operation of this unit requires approximately 9 tons of coffee stems per month, consistent with $75 \%$ of the combined biomass average production of two medium-scale (areas between 5 and 10 ha) coffee farms. At this scale, each farm could produce a minimum of 25 tons per year of dry parchment coffee that yields, in theory, 72 tons per year of coffee stems, following the equivalence reported by Rodriguez [10] of $0.6 \mathrm{~kg}$ of stems per $1 \mathrm{~kg}$ of coffee cherries.

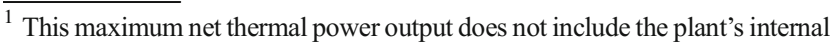
heat demand.
}

This amount of biomass, although is well above the system's resource demand, is also constrained by each farms management systems and their coffee plantations age (generally requiring pruning after 5 to 6 years of cultivation [75]). This implies that storing facilities in the farms would be likely necessary to facilitate sustained feedstock availability and protect the coffee wood from rain and prevent decomposition. Direct application to smallscale farms ( $\sim 1-5$ ha of cultivated land) would be less viable as it would require the integration of several small farms to guarantee a regular biomass feedstock supply. Instead, small-farm holders could beneficiate of the bioenergy supply to community-based coffee processing plants, as they usually organized themselves in cooperatives for the coffee processing and trade.

An initial country-level estimation of the total coffee stem potential of 3,000,000-ton dry coffee wood [29] indicates that sustainable utilization of the residue could yield a biomass availability of 1,500,000-ton dry coffee wood. This considers that approximately $50 \%$ of total residues can be removed sustainably to avoid soil degradation [48]. This biomass resource could supply the feedstock requirements of 20,000 gasification-ICE plants of similar operation capacity, having the potential to contribute with $270 \mathrm{MW}$ of power installed capacity through the implementation of distributed generation systems in the rural regions of Colombia. This would have a positive impact from small to large-scale coffee farmers in the country, with direct application in coffee farms or through their deployment in community coffee processing plants. This significant bioenergy potential, yet, requires further research to evaluate how the biomass availability and energy demand balance behaves across the coffee regions in Colombia by conducting a detailed geographical biomass supply-energy demand analysis.

\section{Conclusions}

This study investigates the potential and feasibility of gasifying coffee stems to produce electricity and low-grade heat for 
Table 8 Heat exchanger main characteristics of heat recovery stages

\begin{tabular}{|c|c|c|c|c|c|}
\hline \multicolumn{6}{|l|}{ Heat recovery stages 1} \\
\hline Heat exchanger 1 (PGAS-HX1) & Producer gas & Gasifying air & Heat exchanger 2 (PGAS-HX2) & Producer gas & Drying air \\
\hline$T_{\text {in }}$ & $792.3^{\circ} \mathrm{C}$ & $25{ }^{\circ} \mathrm{C}$ & $T_{\text {in }}$ & $699.5^{\circ} \mathrm{C}$ & $25^{\circ} \mathrm{C}$ \\
\hline$T_{\text {out }}$ & $699.5^{\circ} \mathrm{C}$ & $250^{\circ} \mathrm{C}$ & $T_{\text {out }}$ & $120^{\circ} \mathrm{C}$ & $50.6^{\circ} \mathrm{C}$ \\
\hline Mass flow & $68 \mathrm{~kg} \mathrm{~h}^{-1}$ & $42 \mathrm{~kg} \mathrm{~h}^{-1}$ & Mass flow & $68.7 \mathrm{~kg} \mathrm{~h}^{-1}$ & $2165.6 \mathrm{~kg} \mathrm{~h}^{-1}$ \\
\hline \multicolumn{3}{|c|}{ Maximum heat duty $2.69 \mathrm{~kW} / \mathrm{LMTD} 463{ }^{\circ} \mathrm{C}$} & \multicolumn{3}{|c|}{ Maximum heat duty $15.6 \mathrm{~kW} / \mathrm{LMTD} 235.6^{\circ} \mathrm{C}$} \\
\hline \multicolumn{6}{|l|}{ Heat recovery stage 2} \\
\hline Heat exchanger 3 (FGAS-HX) & Flue gas & Water & Heat exchanger 4 (AIR-HX) & Hot water & Drying air \\
\hline$T_{\text {in }}$ & $600^{\circ} \mathrm{C}$ & $25^{\circ} \mathrm{C}$ & $T_{\text {in }}$ & $91{ }^{\circ} \mathrm{C}$ & $25^{\circ} \mathrm{C}$ \\
\hline$T_{\text {out }}$ & $120^{\circ} \mathrm{C}$ & $91{ }^{\circ} \mathrm{C}$ & $T_{\text {out }}$ & $28^{\circ} \mathrm{C}$ & $50{ }^{\circ} \mathrm{C}$ \\
\hline Mass flow & $529.8 \mathrm{~kg} \mathrm{~h}^{-1}$ & $280 \mathrm{~kg} \mathrm{~h}^{-1}$ & Mass flow & $280 \mathrm{~kg} \mathrm{~h}^{-1}$ & $3134.3 \mathrm{~kg} \mathrm{~h}^{-1}$ \\
\hline \multicolumn{3}{|c|}{ Maximum heat duty $23.21 \mathrm{~kW} / \mathrm{LMTD} 270.5^{\circ} \mathrm{C}$} & \multicolumn{3}{|c|}{ Maximum heat duty $22.12 \mathrm{~kW} / \mathrm{LMTD} 23.7^{\circ} \mathrm{C}$} \\
\hline
\end{tabular}

the coffee farms at suitable operating scales, using the coffee sector in Colombia as a case study. It provides useful insight into the energy potential of locally available coffee residues to deliver bioenergy for the coffee rural sector and also identifies key steps that could contribute to the implementation of these bioenergy systems within coffee farms in Colombia. These insights could be used as a baseline to evaluate the feasibility of deploying this bioenergy applications inother coffeeproducing countries, delivering wider impacts.

The simulation results showed that coffee gasification could generate a producer gas with an LHV of 5.6 $\mathrm{MJ} \mathrm{Nm}^{-3}$, fit to be used as fuel in ICEs for power generation and yielding a cold gas efficiency of $71 \%$. The recovery of the low-grade heat from the gas cooling stages for internal and external heat demand (e.g. coffee air-drying) could improve the whole process performance $\left(\eta_{\text {global }}=45.6 \%\right)$. This additional heat input could be valuable for the coffee agro-industry, where the fuel for coffee drying represents the highest share in the cost structure of this processing stage.

The analysis of the energy demand and coffee stem availability within the Colombian coffee farms indicates that small- scale gasifier-ICE systems could deliver both, the electricity and heat requirements of large-scale coffee farms or community coffee processing plants. To complement the balance, the extension of large coffee farms or combined biomass supply of small and medium farms using community coffee processing plants could potentially provide a sustained biomass resource to operate the gasification plant. Alternatively, the system could be scaled down to serve the energy demand of smaller coffee farms also, yet at smaller scales, the heat recovery could be less feasible.

Overall, relevant findings emerge from the results of this research which could contribute to feasibible implementations of this coffee residue-based bioenergy systems as follows:

1. Recovering and integrating the low-grade heat recovery is key to increase the (cogeneration) process efficiency; its potential application within the coffee processing chain also enhances the relevance of this bioenergy system for the coffee rural sector.

2. Managing certain biomass and gasifier operating parameters, such as the biomass $\mathrm{MC}$, equivalence ratio and
Fig. 9 Effect of gasifying air temperature on gas LHV and CGE

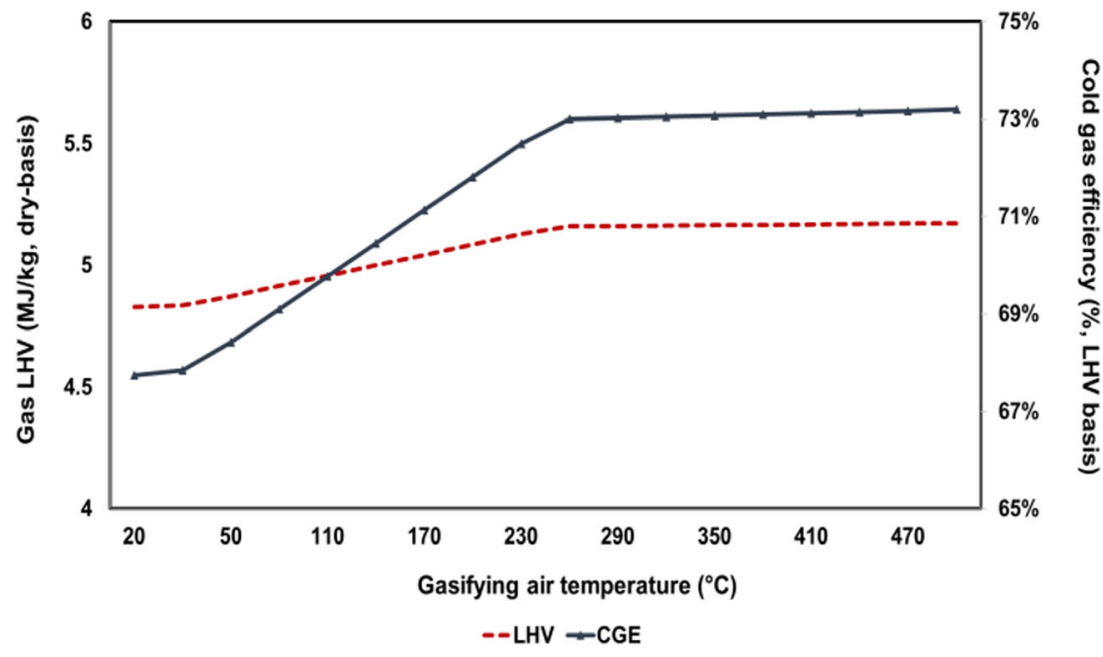




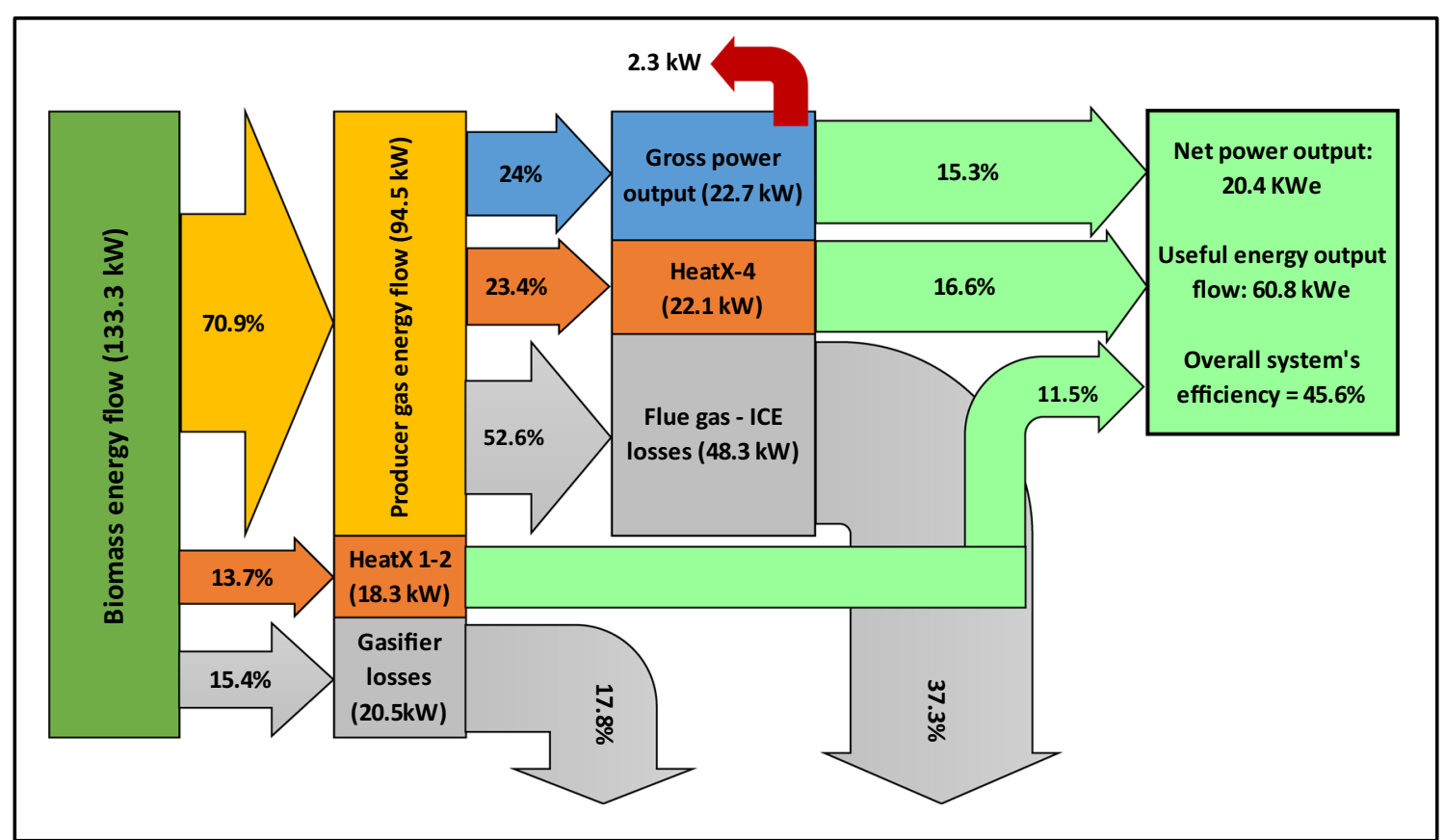

Fig. 10 Energy flow balance (Sankey chart) of the biomass gasifier-ICE system

gasifying air temperature, over an optimum range for fixed bed gasifiers can enhance the gas LHV. This impacts positively the gasifier performance and the whole system's efficiency.

3. Balancing the biomass supply and the energy demand at coffee farms level is a vital factor to determine the scale of operation and feasibility of using these coffee residues in a small-scale gasification systems for power and heat generation.

Finally, more efficient utilization of this crop residue, such as in this bioenergy system, could lead also into positive environmental and economic impacts if practices as coffee stem burning in rural cookstoves and fossil fuel consumption for coffee drying was to be replaced. Though, for claiming such benefits, a complete environmental and economic assessment at the coffee sector level is crucial to gain a comprehensive understanding of the environmental trade-offs and economic feasibility of implementing these systems. Both, the environmental and economic assessment are part of the ongoing work of this research.

Funding information This work is supported by the doctoral scholarship funded by the "Fondo de CTeI del Sistema General de Regalías del Departamento del Atlántico" within the Doctoral scholarship call 673 of 2014 "Formación de Capital Humano de Alto Nivel para el Departamento del Atlántico" in Colombia.

Open Access This article is distributed under the terms of the Creative Commons Attribution 4.0 International License (http:// creativecommons.org/licenses/by/4.0/), which permits unrestricted use, distribution, and reproduction in any medium, provided you give appropriate credit to the original author(s) and the source, provide a link to the Creative Commons license, and indicate if changes were made.

\section{References}

1. FAO, 2015"FAO Statistical Pocketbook Coffee 2015," Rome,

2. Murthy PS, Naidu MM (2012) Sustainable management of coffee industry by- products and value addition-A review. Resour Conserv Recycl 66:45-58

3. ICO, 2017"Country Data on the Global Coffee Trade," International Coffee Organization. [Online]. Available: http:// www.ico.org/profiles_e.asp. [Accessed: 05-Feb-2018]

4. ICO,2018 “Annnual Review 2016/2017,” London

5. The World Bank,2017 "World Bank List of Economies in 2017." Washington, DC.,

6. IEA,2017 "Energy Access Database," World Energy Outlook, [Online]. Available: http://www.iea.org/energyaccess/database/. [Accessed: 30-Jan-2018]

7. Mussatto SI, Machado EMS, Martins S, Teixeira JA (2011) Production, composition, and application of coffee and its industrial residues. Food Bioprocess Technol 4(5):661-672

8. de Protásio TP, Bufalino L, Tonoli GHD, Junior MGG, Trugilho PF, Mendes LM (2013) Brazilian lignocellulosic wastes for bioenergy production: characterization and comparison with fossil fuels. BioResources 8(1):1166-1185

9. L. S. Oliveira and A. S. Franca, 2015 An overview of the potential uses for coffee husks in Coffee in health and disease prevention, pp. 283-291

10. N. Rodríguez Valencia and D. Zambrano Franco, 2010“Los subproductos del café: fuente de energía renovable," Manizales,

11. NL Agency,2012 "Biomass business opportunities Viet Nam," Utrecht,

12. de Oliveira JL, da Silva JN, Pereira EG, Filho DO, Carvalho DR (2013) Characterization and mapping of waste coffee and 
eucalyptus production in Brazil for thermochemical conversion of energy via gasification. Renew Sust Energ Rev 21:52-58

13. Hughes SR, López-Núñez JC, Jones MA, Moser BR, Cox EJ, Lindquist M, Galindo-Leva LÁ, Riaño-Herrera NM, RodriguezValencia N, Gast F, Cedeño DL, Tasaki K, Brown RC, Darzins A, Brunner L (2014) Sustainable conversion of coffee and other crop wastes to biofuels and bioproducts using coupled biochemical and thermochemical processes in a multi-stage biorefinery concept. Appl Microbiol Biotechnol 98:8413-8431

14. Leinonen A, Cuong ND (2013) Development of biomass fuel chains in Vietnam. VTT Technol 134:120

15. Duarte A, Sarache W, Costa Y (2016) Biofuel supply chain design from coffee cut stem under environmental analysis. Energy 100: 321-331

16. García C, Peña A, Betancourt R, Cardona C (2018) Energetic and environmental assessment of thermochemical and biochemical ways for producing energy from agricultural solid residues: Coffee Cut-Stems case. J Environ Manag 216:160-168

17. UPME, 2015“Integración de las energías renovables no convencionales en Colombia," Bogotá,

18. T. Gómez-Navarro and D. Ribó-Pérez, "Assessing the obstacles to the participation of renewable energy sources in the electricity market of Colombia," Renew Sust Energ Rev., vol. 90, no. March, pp. 131-141, 2018

19. XM S.A.,2017 "Capacidad efectiva por tipo de generacion," Medellin,

20. M. A. Gonzalez-Salazar, M. Morini, M. Pinelli, P. R. Spina, M. Venturini, M. Finkenrath, W.R. Poganietz, "Methodology for estimating biomass energy potential and its application to Colombia," Appl Energy, vol. 136, no. 0, pp. 781-796, 2014

21. Hernandez JA, Velasco D, Trujillo CL (2011) Analysis of the effect of the implementation of photovoltaic systems like option of distributed generation in Colombia. Renew Sust Energ Rev 15(5): 2290-2298

22. Gaona EE, Trujillo CL, Guacaneme JA (2015) Rural microgrids and its potential application in Colombia. Renew Sust Energ Rev 51:125-137

23. Congreso de Colombia, 2014 Ley 1715 del 13 Mayo de 2014, no. May. Colombia, , p. 13

24. S. Bachra, M. Buckley-Pearson, N. D. N. Garcia, and M. McQuillan, 2015“Market information report: Colombia," Ontario, Canada

25. Gonzalez-Salazar MA, Venturini M, Poganietz WR, Finkenrath M, Kirsten T, Acevedo H, Spina PR (2016) Development of a technology roadmap for bioenergy exploitation including biofuels, wasteto-energy and power generation \& CHP. Appl Energy 180:338-352

26. FNC, 2014“Ensayos sobre economía cafetera," Bogotá,

27. H. Escalante, J. Orduz, H. Zapata, M. Cardona, and M. Duarte, 2011"Atlas del potential energetico de la biomasa residual en Colombia. Reporte preparado para la Unidad de Planeación Minero Energética (UPME) y el Instituto de Hidrología, Meteorología y Estudios Ambientales de Colombia (IDEAM)," Bogotá

28. García C, Moncada J, Aristizábal V, Cardona C (Mar. 2017) Techno-economic and energetic assessment of hydrogen production through gasification in the Colombian context: Coffee CutStems case. Int J Hydrog Energy 42(9):5849-5864

29. Oliveros-Tascón CE, Sanz Uribe JR, Rodriguez Valencia N (2017) Evaluacion de un gasificador de flujo descendente utilizando astillas de madera de cafe. Rev del Cent Nac Investig CafeCenicafe 68(2):61-75

30. A. Bauen, G. Berndes, M. Junginger, F. Vuille, and M. Londo,2009 "Bioenergy - a sustainable and reliable energy source," Rotorua,

31. Nguyen TLT, Hermansen JE, Nielsen RG (2013) Environmental assessment of gasification technology for biomass conversion to energy in comparison with other alternatives: the case of wheat straw. J Clean Prod 53:138-148

32. P. Basu, 2013 "Gasification theory and modeling of gasifiers," in Biomass gasification, pyrolysis and torrefaction - practical design and theory, 2nd ed., Elsevier Inc., , pp. 117-165

33. Buekens AG, Schoeters JG (1985) Modelling of biomass gasification, in Fundamentals of Thermochemical Biomass Conversion. Elsevier, London

34. Antonopoulos IS, Karagiannidis A, Gkouletsos A, Perkoulidis G (2012) Modelling of a downdraft gasifier fed by agricultural residues. Waste Manag 32(4):710-718

35. M. Vaezi, M. Moghiman, M. Charmchi, and M. Passandideh-Fard, 2008"Modeling biomass gasification: a new approach to utilize renewable soruces of energy," in 2008 ASME International Mechanical Engineering Congress and Exposition,, pp. 1-9

36. Shen L, Gao Y, Xiao J (2008) Simulation of hydrogen production from biomass gasification in interconnected fluidized beds. Biomass Bioenergy 32:120-127

37. Begum S, Rasul MG, Akbar D, Ramzan N (2013) Performance analysis of an integrated fixed bed gasifier model for different biomass feedstocks. Energies 6(12):6508-6524

38. Beheshti SM, Ghassemi H, Shahsavan-Markadeh R (2015) Process simulation of biomass gasification in a bubbling fluidized bed reactor. Energy Convers Manag 94:345-352

39. Nikoo M, Mahinpey N (2008) Simulation of biomass gasification in fluidized bed reactor in ASPEN PLUS. Biomass Bioenergy 32(12):4545-4555

40. Ramzan N, Ashraf A, Naveed S, Malik A (2011) Simulation of hybrid biomass gasification using Aspen plus: a comparative performance analysis for food, municipal solid and poultry waste. Biomass Bioenergy 35:3962-3969

41. Doherty W, Reynolds A, Kennedy D (2010) Computer simulation of a biomass gasification-solid oxide fuel cell power system using Aspen Plus. Energy 35(12):4545-4555

42. Doherty W, Reynolds A, Kennedy D (2009) The effect of air preheating in a biomass CFB gasifier using ASPEN Plus simulation. Biomass Bioenergy 33(9):1158-1167

43. W. Doherty, A. Reynolds, and D. Kennedy, 2013“Aspen Plus Simulation of Biomass Gasification in a Steam Blown Dual Fluidised Bed," in Materials and processes for energy: communicating current research amd technological developments, A. Mendez-Vilas, Ed. , pp. 212-220

44. Ruiz JA, Juárez MC, Morales MP, Muñoz P, Mendívil MA (2013) Biomass gasification for electricity generation: review of current technology barriers. Renew Sust Energ Rev 18:174-183

45. Kirkels AF, Verbong GPJ (2011) Biomass gasification: still promising? A 30-year global overview. Renew Sust Energ Rev 15:471481

46. P. Basu, 2013 "Design of Biomass Gasifiers," in Biomass Gasification, Pyrolysis and Torrefaction - Practical design and theory, 2nd ed., Dalhousee University and Greenfield Research Incorporated, Ed. London: Elsevier Inc., , pp. 249-313

47. Pereira EG, da Silva JN, de Oliveira JL, Machado CS (2012) Sustainable energy: a review of gasification technologies. Renew Sust Energ Rev 16(7):4753-4762

48. Romo Ortega N, Toro AF, Flores Pardo LM, Cañas Velasco A (2011) Evaluación de las propiedades fisicoquímicas y térmicas de tallos de café y su análisis económico para la producción de pellets como biocombustible sólido. Ing Recur Nat y del Ambient 10:79-91

49. Basu P (2013) "Biomass Characteristics," in Biomass Gasification, Pyrolysis and Torrefaction - Practical design and theory, 2nd edn. Elsevier Inc., London, pp 47-86

50. Hasler P, Nussbaumer T (1999) Gas cleaning for IC engine applications from fixed bed biomass gasification. Biomass Bioenergy $16: 385-395$ 
51. Woolcock PJ, Brown RC (2013) A review of cleaning technologies for biomass-derived syngas. Biomass Bioenergy 52:54-84

52. Raman P, Ram NK, Gupta R (2013) A dual fired downdraft gasifier system to produce cleaner gas for power generation : design, development and performance analysis. Energy 54:302-314

53. Laurence LC, Ashenafi D (2012) Syngas treatment unit for small scale gasification - application to IC engine gas quality requirement. J Appl Fluid Mech 5(1):95-103

54. Heidenreich S, Foscolo PU (2015) New concepts in biomass gasification. Prog Energy Combust Sci 46:72-95

55. J. Ahrenfeldt, R. Bain, B. van de Beld, S. C. Bhattacharya, and H. Boerrigter, 2005"Practical aspects of biomass gasification," in Handbook biomass gasification, H. Knoef, Ed. Enschede: BTG Biomass Technology Group, , p. 378 p

56. Sinnot RK (2005) Chemical Engineering Design, 4th edn. Elsevier, Oxford

57. R. H. Perry, D. W. Green, and J. O. Maloney,1997 Perry's chemical engineering handbook, Seventh ed. New York,

58. Fendt S, Tremel A, Gaderer M, Spliethoff H (2012) The potential of small-scale SNG production from biomass gasification. Biomass Convers Biorefinery 2(3):275-283

59. Roa-Mejía G, Oliveros-Tascón CE, Parra-Coronado A, Ramírez CA (2000) El secado mecánico del café. Chinchina, Caldas

60. EPA,2017 Catalog of CHP Technologies, Washington, DC,

61. Hagos FY, Aziz ARA, Sulaiman SA (2014) Trends of syngas as a fuel in internal combustion engines. Adv Mech Eng 2014

62. Molino A, Chianese S, Musmarra D (2016) Biomass gasification technology: the state of the art overview. J Energy Chem 25:10-25

63. Perez NP, Machin EB, Pedroso DT, Roberts JJ, Antunes JS, Silveira JL (2015) Biomass gasification for combined heat and power generation in the Cuban context: energetic and economic analysis. Appl Therm Eng 90:1-12

64. All Power Labs, "PP30 Specification Sheet," 2018. [Online]. Available: http://www.allpowerlabs.com/products/productoverview. [Accessed: 26-Oct-2018]

65. Indrawan N, Thapa S, Bhoi PR, Huhnke RL, Kumar A (2017) Engine power generation and emission performance of syngas generated from low-density biomass. Energy Convers Manag 148: 593-603
66. Sierra E, Acién FG, Fernández JM, García JL, González C, Molina E (May 2008) Characterization of a flat plate photobioreactor for the production of microalgae. Chem Eng J 138(1-3):136-147

67. Barman NS, Ghosh S, De S (2012) Gasification of biomass in a fixed bed downdraft gasifier - a realistic model including tar. Bioresour Technol 107:505-511

68. Zainal Z, Ali R, Lean CH, Seetharamu KN (2001) Prediction of performance of a downdraft gasifier using equilibrium modeling for different biomass materials. Energy Convers Manag 42(12):1499 1515

69. Z. Yao, S. You, T. Ge, and C. H. Wang, 2018"Biomass gasification for syngas and biochar co-production: energy application and economic evaluation,” Appl Energy, vol. 209, no. October 2017, pp. $43-55$,

70. C. R. Altafini, P. R. Wander, and R. M. Barreto, 2003 "Prediction of the working parameters of a wood waste gasifier through an equilibrium model," Energy Convers. Manag.,

71. Vera D, de Mena B, Jurado F, Schories G (2013) Study of a downdraft gasifier and gas engine fuelled with olive oil industry wastes. Appl Therm Eng 51:119-129

72. Baratieri M, Baggio P, Bosio B, Grigiante M, Longo GA (2009) The use of biomass syngas in IC engines and CCGT plants: a comparative analysis. Appl Therm Eng 29:3309-3318

73. D. Arenas Castellanos, "Propuesta de diseño de un proceso para la generación de energía eléctrica a partir de los residuos de la producción de cafe," Pontificia Universidad Javeriana, 2009

74. Oliveros Tascón CE, Sanz Uribe JR, Ramirez Gomez CA, Penuela Martinez AE (2009) Aprovechamiento eficiente de la energía en el secado mecánico del café. Chinchina, Caldas

75. Arcila Pulgarín J (2007) Renovación y administración de los cafetales para estabilizar la producción de la finca, in Sistemas de producción de café en Colombia, 1st edn. Cenicafe, Chinchina, Caldas, pp 144-160

Publisher's note Springer Nature remains neutral with regard to jurisdictional claims in published maps and institutional affiliations. 